\title{
The Occurrence, Chemical Quality and Use of Ground Water in the Ţabulbah Area, Tunisia
}

GEOLOGICAL SURVEY WATER-SUPPLY PAPER 1757-E

Prepared in cooperation with the Groupe d'Hydraulique et l'Equipement Rural, Tunisian Secretariat of State for Agriculture under the auspices of the United States Agency for International Develop-

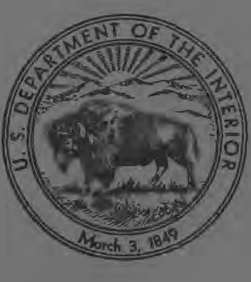
ment 


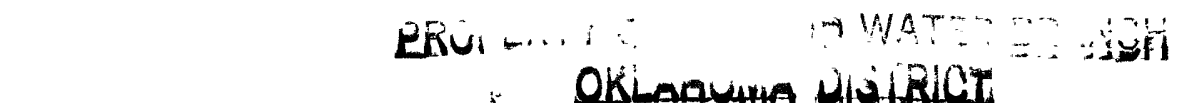
The Occurrence, Chemical Quality and Use of Ground Water in the Tुabulbah Area, Tunisia

By L. C. DUTCHER and H. E. THOMAS

CONTRIBUTIONS TO THE HYDROLOGY OF AFRICA AND THE MEDITERRANEAN REGION

GEOLOGICAL SURVEY WATER-SUPPLY PAPER 1757-E

Prepared in cooperation with the Groupe d'Hydraulique et l'Equipement Rural, Tunisian Secretariat of State for Agriculture under the auspices of the United States Agency for International Develop-

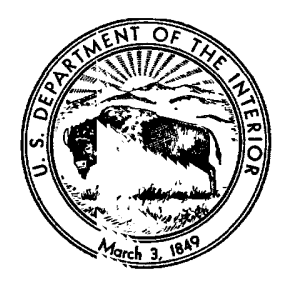
ment 
UNITED STATES DEPARTMENT OF THE INTERIOR

STEWART L. UDALL, Secretary

\author{
GEOLOGICAL SURVEY \\ William T. Pecora, Director
}

For sale by the Superintendent of Documents, U.S. Government Prirting Office Washington, D.C. 20402 


\section{CONTENTS}

Page

Introduction

Acknowledgments

Physical environment._.

Geology

Soils_.....

Climate...

Human adaptation to environment.

Population

Agricultural economy

Program of drilling test wells.... 9

Occurrence of ground water.

Source, movement, and discharge

Water-level fluctuations in wells...

Rate of water-level decline..... 17

Quality of ground water. 18

Vertical and horizontal zonation of water........ 20

Sea- or sabkha-water encroachment._.

Ground water in storage..... 23

Ground-water storage capacity of the deposits

Usable ground water in storage. 26

Adequacy of the water supply

Reservoir management and use....... 28

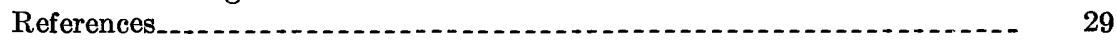

\section{ILLUSTRATIONS}

[Plates are in pocket]

Plate 1. Map showing location of wells, depth to water, ground-rvater storage units, and lines of sections.

2. Diagrammatic section showing electric logs, lithology, and water quality of test wells.

3. Sections showing depth to water, dissolved-solids content; and quality of water.

4. Hydrographs showing water-level fluctuations.

5. Map showing chemical quality of water in the shallow grc undwater body.

Frgure 1. Index map of Tunisia...........

2. Annual precipitation at Tabulbah and Sūsah..........

3. Wells less than 500 meters from test well 1. . 


\title{
CONTRIBUTIONS TO THE HYDROLOGY OF AFRICA AND THE MEDITERRANEAN REGION
}

\section{THE OGGURRENGE, GHEMICAL QUALITY, AND USE OF GROUND WATER IN THE TABULBAH AREA, T'JNISIA}

\author{
By L. C. Dutcher and H. E. Thomas
}

\begin{abstract}
The major problem in the Tabulbah area, Tunisia, is that the current (1963) rate of pumping from wells is depleting the ground-water reservoir. The water being pumped from storage is of better quality than some of the water that replenishes the aquifers; so, even if the rate of withdrawal is reduced, the quality of water in some wells may deteriorate.

In the vicinity of Tabulbah, which lies in the As Sāhil region along the coast of central Tunisia, there is a shallow body of usable ground water which is bounded on three sides by saline waters. Withdrawals to date (1963) rave created hydraulic gradients favorable for encroachment of sea water from the Mediterranean and of salt water from the Sabkhat Matā'al Muknin, a saline lake. At depths greater than about 95 meters the ground water is more mineralized than at lesser depths, and brine aquifers are encountered below 160 meters. Water which locally enters the shallow body from above-by slow drainage from finegrained sediments and by recharge from precipitation-may also be mineralized. Optimum utilization of this ground-water body cannot be achieved $\mathrm{ky}$ adherence to the principle of perennial yield. Instead, the fresh water should be developed by mining techniques, including blending of waters to produce a prod'ct of usable quality and depletion at a rate sufficient to prevent excessive contamination. Thus, this water is classified as a nonreplenishable resource which will last for several years and perhaps for several decades, depending upon the rate of depletion.

Since 1940 local water levels have declined more than 30 meters, and the chemical quality of water in wells has deteriorated nearly everywhere except in an area of about 8 square kilometers which is underlain by ground water of the best chemical quality (having 2,000 parts per million or less of dissolved solids). Encroachment of sea water is a threat; its effects have already been observed in a very limited area. A more serious threat to the body of fresh ground water, perhaps, is chemical contamination from inflow of poor-quality water from surrounding deposits. Even under natural conditions, before extensive development, much of the area was probably underlain by saline ground water covered by a very thin lens or layer of fresh water that was soon removed after commencement of pumping from closely spaced dug wells. In these areas a marked deterioration of water quality has been reported and observed since 1940 although
\end{abstract}


there has been little or no decline in water levels in wells. In the area of greatest pumping the present rate of water-level decline is estimated to be 2 to 3 meters per year, but elsewhere the decline ranges from a negligible amount to about 1 meter per year.

The total ground-water storage capacity of the area, without regard to the quality of water contained in the deposits, was estimated to be about 220 million cubic meters (180,000 acre-ft). However, the total estimated usable ground water in storage having less than about 4,000 parts per million of dissolved solids was estimated to be only about 61 million cubic meters $(50,000$ acre-ft). Of this amount, only about 28 million cubic meters $(23,000$ acre-ft) probably contains less than 2,000 parts per million of dissolved solids.

Obviously the present rate of ground-water withdrawal cannot be continued indefinitely. On the other hand, a controlled or arbitrary reductior in the rate of pumping might cause a loss of usable ground water in storage through chemical deterioration. The only apparent solution to this problem seems to be the importation of water. In this regard a pipeline is reportedly planned for construction as a part of the Wādi Nābhanah dam and irrigation project. This pipeline could also be used to bring water to the area for recharging the aquifer through the dug wells during periods when the water is not immediately needed elsewhere or during rare floods when the Nābhanah Reservoir is in danger of s?illing. This type of cyclic recharge of the aquifer might result in salvaging water for use and also, by extending the life of the wells, might defer the construction $o^{f}$ an elaborate surface-water distribution system to serve the Tabulbah irrigated lands.

\section{INTRODUCTION}

In the Tabulbah ${ }^{1}$ area, in the Sāhil Sūsah region along the coast of central Tunisia, there is a small, shallow body of usable ground water which is bounded on three sides by saline waters. The area of study covers less than 45 square kilometers bordered on the north by the Mediterranean Sea and on the south by the Sabkhat Mata' al Muknin, a saline lake whose bed is about 5 to 9 meters belc $w$ sea level. Within that area numerous wells have been visited by field crews of Mission Thomas and cataloged by Le Bureau de l'Inventaire des Ressources Hydrauliques (BIRH). (See p. E4.) The vells obtain water from thin beds and lenses of sand which commonly evince poor hydraulic continuity.

In the inventory of wells in Tunisia developed by the Groupe d'Hydraulique et l'Equipement Rural (HER), of the Tunisian Secrétariat d'Etat à l'Agriculture, some wells in the Thal 'llbah area were cataloged as early as 1895. A study of the area was begun in May 1940 but was halted rather abruptly the same year because of World War II. During that study 94 wells were inventoried, and samples of water from each well were analysed (Dutcher and Mahjoub, 1962, table 4). In 1960 the current study was begun by revisiting each of these 94 wells.

\footnotetext{
1 Geographic names used in this report conform to the system adopted by the U.S. Board on Geographic Names, B GN/PCGN system.
} 
The history of the area is one of progressive deepening of wells as water levels declined or of abandonment of wells as the water became unusable because of increasing salinity. Currently (1963), the static level in wells is below sea level throughout most of the area underlain by ground water of the best chemical quality, and in some wells west of Tabulbah the pumping level is more than $40 \mathrm{~m}$ below sea level; several wells have been dug to depths of 60 to $75 \mathrm{~m}$.

Available data for wells-including depths to water (periodic measurements were made in 35 selected wells), conductivity of waters, chemical analyses of waters, driller's logs of wells, and altitudes of wells determined by spirit level-are included in a separate data report (Dutcher and Mahjoub, 1962).

The Tabulbah area is noteworthy because the inhabitants, having depleted the ground-water reservoir to some extent by withdrawals for irrigation, apparently do not have any suitable alternatire but to continue this depletion until the reservoir is exhausted; if the inhabitants had not started this depletion and upset the water balance, they would not have used the fresh-ground-water reservoir to the best advantage. (See p. E27.)

\section{ACKNOWLEDGMENTS}

This report is based on work by Mission Thomas, a sub ection of the Groupe d'Hydraulique et l'Equipement Rural (HER), Tunisian Secrétariat d'Etat à l'Agriculture. Mission Thomas was established as part of a training project to introduce new geohydrologic mapping techniques in Tunisia, within the scope of the U.S. Agency for International Development (US AID) Mission to Tunisia.

The work was under the direction of Lassaâd Ben Osman, Chief Engineer (HER). The first phase was under the supervision of H. E. Thomas, geologist in charge of Mission Thomas, and the later phases were under the supervision of L. C. Dutcher. Messrs. Thomas and Dutcher of the U.S. Geological Survey, Water Resources Division, worked under the direction of G. C. Taylor, Jr., Chief, Foreign Hydrology Section, and did the work in Tunisia under a participatingagency agreement with the US AID Mission.

A preliminary report (in English) on the area was given at the Athens Symposium of the International Association of Scientific Hydrology (Thomas and Dutcher, 1961). The translation of the report into the French language was made by Mohammed Salah Mahjoub, administrative and technical assistant, Mission Thomas.

The writers wish to acknowledge the field help and assistance of the Mission Thomas staff which included Mohammed Lahmar, Thamri Youssef, Abdelaziz el Ghali, Abderrazak el Ghali, El Aloui Tahar, Roland Guez, and others. The drafting work was done 
mainly by Ben Abdallah Hamadi. Also acknowledged is the work of the men and drilling crews of the Subdivision Spéciale des Sondages under the direction of Ahmed Khouadja, Principal Engineer, Chief of Service, without whose assistance the test wells discussed herein could not have been drilled.

Particular acknowledgment is given for the help and coperation of Habib Zebidi, Engineer-in-Charge of the Bureau de l'Inventaire des Ressources Hydrauliques (BIRH) and the engineers and personnel of his staff who provided access to data and administrative support during the investigation. Acknowledgment is also given for the technical and administrative support given by the staff of the US AID Mission to Tunisia under the direction of D. C. Lavergne.

\section{PHYSICAL ENVIRONMENT}

The area considered in this report is about $10 \mathrm{~km}$ long and extends from the towns of Aș Șayyādah, Qașr Hallāl, and Matā' al Muknīn on the west to $\mathrm{Al} \mathrm{Baq}$ alițah on the east; it is about $4 \mathrm{~km}$ wide, and is bordered on the north by the Mediterranean Sea (fig. 1). More than $6 \mathrm{~km}$ of the south border of the area is at the Sabkrat Matá al Muknin, a saline lake that has a bed 5 to $9 \mathrm{~m}$ below sea level and an areal extent of about $50 \mathrm{~km}^{2}$ in winter but much less in summer.

The central part of the area between the two salt-we.ter bodies is relatively flat, the altitude ranging from $30 \mathrm{~m}$ near Qaşr Hallall to 20 $\mathrm{m}$ at Țabulbah and $12 \mathrm{~m}$ near Al Baqālițah. Generally, the descent from this plateau to the Mediterranean is rather abrupt and occurs within a few meters of the shore, but several small ephemeral streans have cut into the plateau for a distance of half a kilometer or more. The southward descent from the plateau to the sabkha is more gradual, generally extending over a kilometer; several streams have established channels approaching $2 \mathrm{~km}$ in length, but their valleys are broader and shallower than those streams draining to the Mediterranean. There are no perennial streams and no fresh-rater springs in the area. All streams are dry except during runoff fror exceptional storms.

\section{GEOLOGX}

The deposits that crop out in the Tabulbah area and those penetrated by existing wells are all presumably of late Pliocene and younger age and are underlain by older Tertiary formations of considerable thickness. Possibly, the fresh-water reservoir, mainly in the Quaternary sediments near Tabulbah, extends downward into the littoral deposits of Pliocene age. The permeable zones in the Tertiary formations at greater depth may contain saline water, according to deep borings elsewhere in As Sāhil region, but a test well at least $1,000 \mathrm{~m}$ deep would be necessary to determine adequately the water 


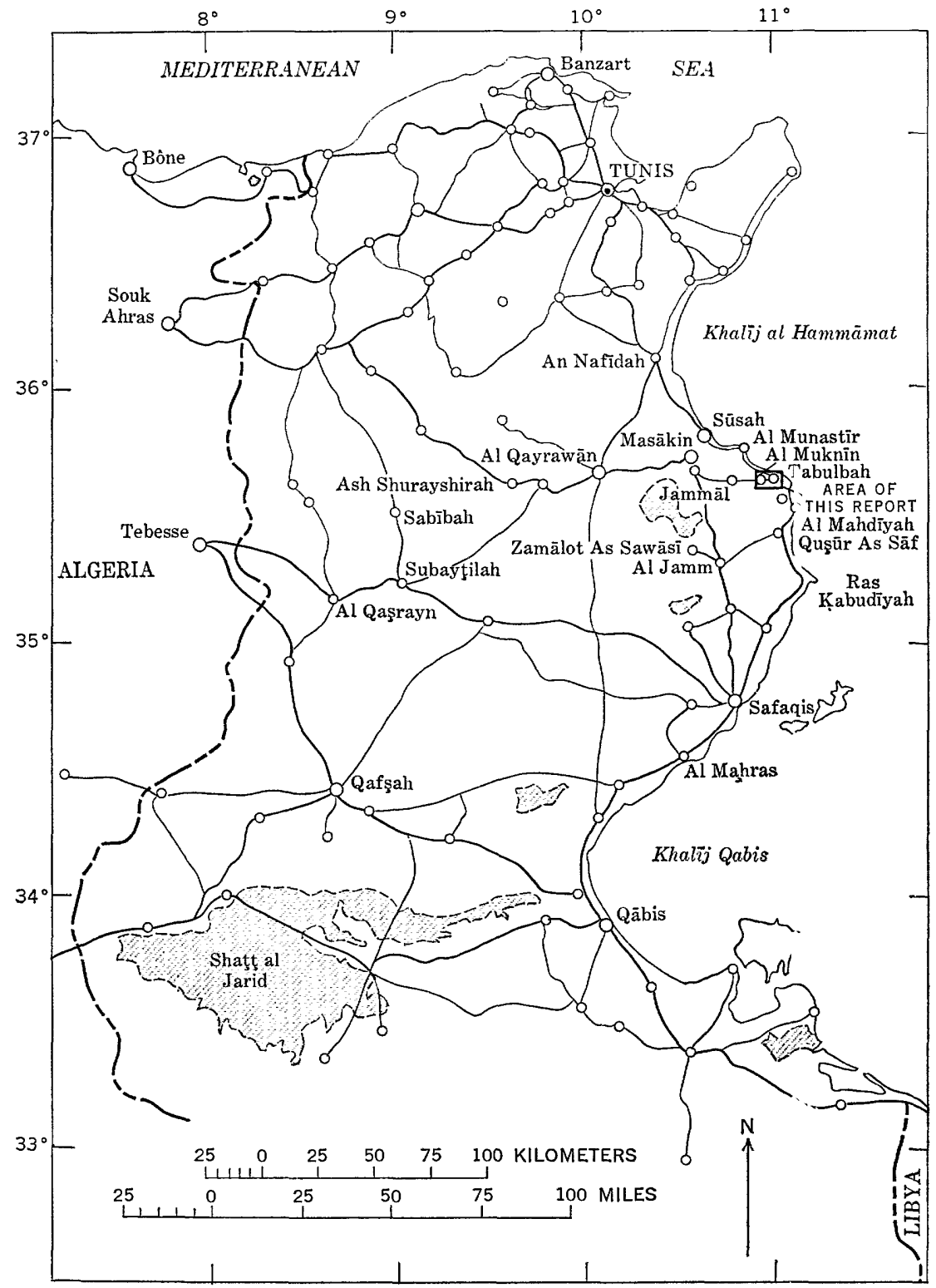

Figure 1.-Map of Tunisia showing area studied. 
quality in the underlying sands of Miocene age. This paper describes only the shallow ground-water body and therefore principally the deposits of Pliocene and Quaternary age.

A calcareous hardpan, or "croute calcaire," underlies almost all the area: it crops out along the north edge of the plateau near the coast, underlies the plateau soils everywhere at very shallow depth, and lies at somewhat greater depth under the slopes that drain to the sabkha. The croute calcaire provides the material for practically all buildings and dwellings, for the walls and superstructures of dug wells, for fences, for cemented conduits to carry water from wells to gardens, and for the roofs at the lower ends of the towpath at many wells. On the other hand, it causes numerous handicaps to agriculture.

Except for croute calcaire, the Quaternary sediments that appear on the surface are of limited areal extent. They include (1) the alluvium in the stream valleys and the colluvium on the steeper slopes, both derived in large part from the croute calcaire, (2) the sands along the Mediterranean coast including littoral, eolian, and fluvial deposits, (3) lacustrine clays along the borders of the sabkha, and (4) fluvial and eolian sands, especially between Tabulk ah and the sabkha but also in some other parts of the area.

According to records from borings, dug wells, and tunnels, the uppermost croute calcaire ranges in thickness from 0.5 to $15 \mathrm{~m}$. At greater depths the Quaternary sediments are mainly cley and silt, with some layers of calcareous hardpan extending down to depths as great as $35 \mathrm{~m}$ and numerous thin beds and lenses of fine sand that constitute the aquifers.

\section{SorLs}

As mapped by Cointepas (1959) the soils in most of the Tabulbah area are clayey, highly calcareous, and laden with fragments of the calcareous hardpan. On the plateau the soil is generally less than $0.4 \mathrm{~m}$ deep. Along the slopes descending toward the sabkha, the soil commonly exceeds $0.8 \mathrm{~m}$ in depth, but there too it is generally underlain by the hardpan. Sandy soils are of limited areal extent, occurring chiefly along the Mediterranean coast and along the slopes bordering the sabkha; there are also saline clay soils bondering the sabkha. Cointepas has classified practically all these soils as "mediocre." The thin soils underlain by calcareous hardpan are considered by him to be best adapted to olive culture, and he rocommends against extensive irrigation of these soils because of the danger of waterlogging (engorgement) above the "impermeable" hartpan.

\section{CLIMATE}

In 31 years of record the average annual rainfall at Tabulbah has been 375 millimeters, of which $330 \mathrm{~mm}$ have been received during the 
7 months September to March. On the average, October is the wettest month, and there is subsequently a gradual and progressive decline in precipitation for the next 6 months. The area has a fall and winter growing season, being almost frost free. The summer is arid, but more humidity and lower maximum temperatures prevail here than in inland areas because of the influence of the Mediterranean Sea. Nevertheless, the average annual evaporation (measured at Sūsah) is more than three times as great as the average \&nnual precipitation, and the climate of As Săhil region is distinctly arid. Winds that are hazardous to agriculture include occasional hot winds (siroc$\cos$ ) from the south during the summer and more frequent $r$ orth winds during other times of the year.

The actual weather includes wide variations from the average, particularly in precipitation, which has ranged from $141 \mathrm{~mm}$ in the agricultural year 1946 to $906 \mathrm{~mm}$ in 1932 (fig. 2). In more than onefourth of the years of record the precipitation has been less than 250 $\mathrm{mm}$, and in more than one-fourth of the years it has exceeded 450 $\mathrm{mm}$. Furthermore, the record for Thabulbah and the longer record for Sūsah indicate an alternation of wetter periods (1890-94, 1902-07, 1919-21, 1932-36, 1949-52, 1956-59) and more extended periods of drought (fig. 2). During each of the 3 wettest years of record, precipitation at Tabulbah has totaled $200 \mathrm{~mm}$ or more within 6 months; in 2 of these years, this amount occurred entirely during the period September to January. Such heavy storms in the fall, following the long dry summer, are conducive to floods and erosion.

\section{HUMAN ADAPTATION TO ENVIRONMENT}

In many respects the environment of the Tabulbah area, is a challenge to mankind, and mankind has responded to this challenge with varying degrees of ingenuity. Human adaptation to it doubtlessly began centuries ago, as exemplified by the development of the olive, which became the principal agricultural product because it could adapt to the marginal and variable water supply. The building of dikes or levees around individual olive groves or subdivisions is s.lso a wellestablished practice designed to hold rain where it falls in order to obtain the maximum benefit from the limited precipitation. Several wells have been pointed out as being of Roman origin. They appear to be ancient indeed, but we do not have enough bac'rground in archeology to verify or refute the claims.

Although it was not possible to identify a Roman well, we are aware that the limited water resources throughout Tunisia have sustained peoples of numerous civilizations throughout more than 2,000 years of recorded history by means of streams, springs, galleries, cisterns, wells, and the moisture in the soil that produces crops. To the extent 


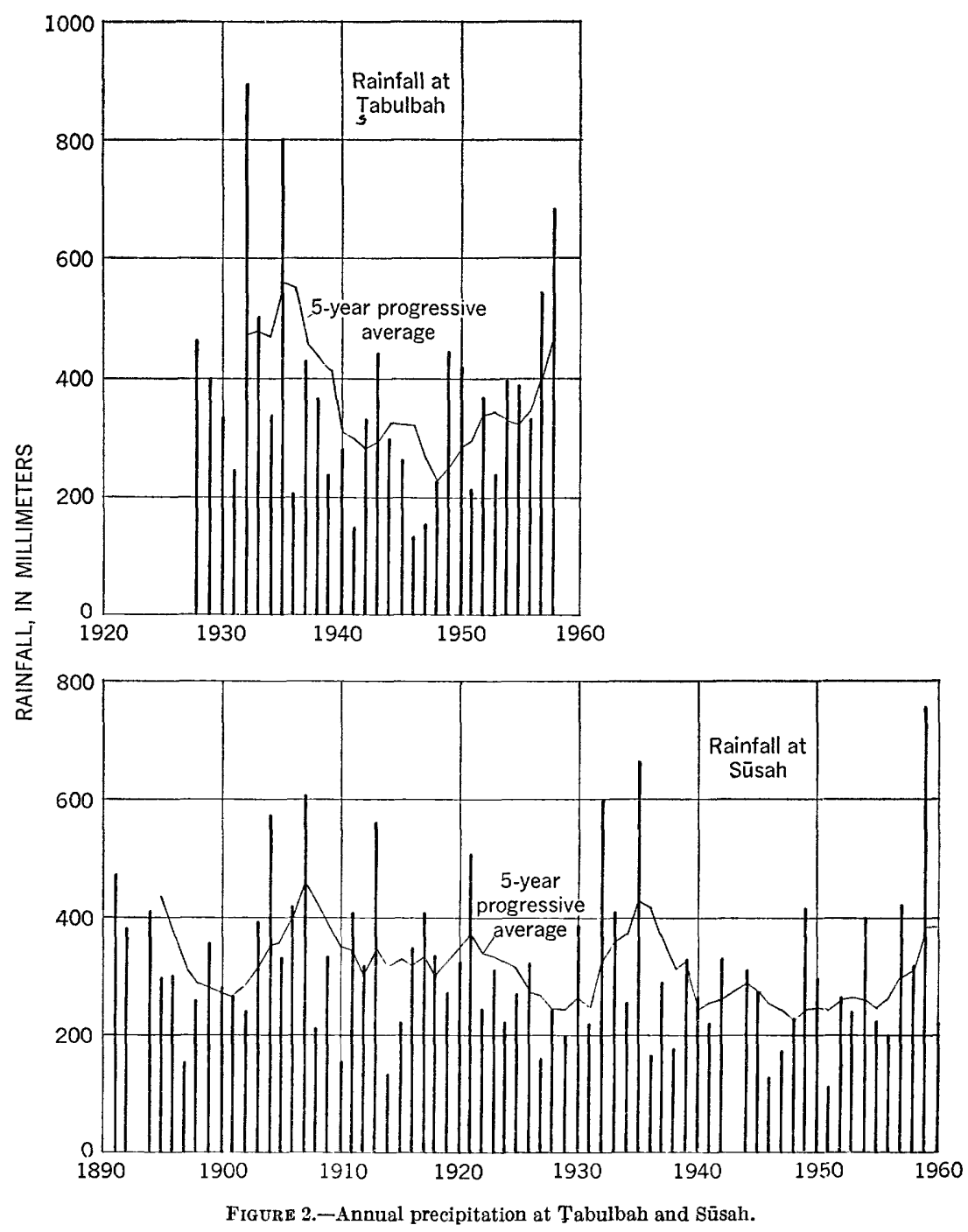

that these sources provide a sustained yield throughout the centuries, past or future, they must have been and must continue to be replenished by precipitation. Throughout Tunisia the maintenance of a safe yield, or perennial yield (bilan d'eau), by limiting the withdrawals from wells to the amount that can be replenished, is fundamental in the philosophy of administration of the water resources, and inevitably so if we are to attempt to see as far into the future as we are able to look into the past. The applicability of this philosophy in the Trabulbah area is discussed in a later section "Source, movement, and discharge," page E14. 


\section{POPULATION}

As of 1959 , the population of the Tabulbah area was about 65,000 , of whom about 44,000 were concentrated in the cities of $\mathrm{Al}$ Muknin $(20,000)$, Qaşr Hallāl $(8,300)$, Tabulbah $(6,200)$, As Sayyādah $(5,700)$, and Al Baqālițah $(3,300)$. TThere is relatively little industrial development in any of these towns, and the urbanites are therefore almost as dependent upon the agricultural economy as are their rur?l brethren.

\section{AGRICULTURAL ECONOMY}

Olives are the principal product of the area, and aerial photographs indicate that approximately 70 percent of the land is coverad by olive groves, especially on the plateau. In many places the land between the olive trees is planted in forage. Small gardens may alsc be planted for the winter growing season. and in years with a favorable amount and distribution of rainfall these gardens may yield good crops for market without irrigation. Dryfarming, however, is hazardous because of the frequency of drought years.

Irrigated tracts of vegetables and fruits, some being situated among the olive groves and others replacing them completely, ar 3 numerous and becoming more so. All water for irrigation comes from dug wells. Having cataloged more than 625 wells, we estimate that th are may be a thousand within the $45 \mathrm{~km}^{2}$ area (pl. 1). Water is withdrawn from most of these wells in leather bags (dalous) by camels or oxen. Currently, 54 wells are equipped with motor-driven pumps; 45 of the wells are within $3 \mathrm{~km}$ west of Tabulbah (pl. 1). All hand-dug wells that had been dug to depths of only a few meters belor the static water level have required periodic deepening. The development of water resources for irrigation has insured satisfactory crops each year, which are independent of the vagaries of precipitation. This is of special value to the Țabulbah area, which can thus export winter vegetables and fruits as first arrivals on local and European markets.

\section{PROGRAM OF DRILLING TEST WELLS}

Certain questions concerning the hydrology of the Thabulbah area could not be answered using data derived from existing hand-dug wells and development. These are: the depth to which the sediments are saturated with usable water; hydrologic characteristics of the deeper aquifers and the quality of water in them; and the existing and potential contamination by water from the sea, the sabkha, or saline aquifers. In an effort to obtain this information, a program of drilling test wells was begun in January and terminated in August 1961. 
In all, 1,162.7 $\mathrm{m}$ of test hole was drilled at four sites (Dutcher and Mahjoub, 1962, table 5). Only one test well was cased, however, and so adequate production and water-quality data were not obtained. Also, a test well at least $1,000 \mathrm{~m}$ deep would be necessary to determine if potable ground water is present in the sand of Vindobonian age underlying the area.

The first test well (BIRH catalog No. 9932) was drilled about $1 \mathrm{~km}$ west of Tabulbah and adjacent to the municipal water tower (château d'eau) which obtains water from a well $44 \mathrm{~m}$ deep (pl. 1). Within $500 \mathrm{~m}$ of this test well there are 50 wells, of which 19 are equipped with motor-driven pumps (fig. 3). Thus, the first test well was in an area of heavy withdrawal, where water is of good quality. The test well had a total depth of $282 \mathrm{~m}$ (see Dutcher and Mahjoub, 1962, table 5). It penetrated calcareous hardpan to a depth of $12 \mathrm{~m}$, and two other thin layers of calcareous hardpan at between 25 and $35 \mathrm{~m}$. From the water table (at $38 \mathrm{~m}$ ) to a depth of $95 \mathrm{~m}$ the ceposits are prevailingly sandy silt and clay but include six beds of sand with a total thickness of $16 \mathrm{~m}$. On the basis of an electric $\log \mathrm{tl}$ a water in these sands was estimated to contain 600 to 2,000 ppm (parts per million) of dissolved solids. Three additional beds of fine sand totaling $21 \mathrm{~m}$ were logged between 123 and $159 \mathrm{~m}$, witl dissolved solids estimated to range from 3,000 to $4,400 \mathrm{ppm}$. The water in all sands below the depth of $160 \mathrm{~m}$ was saline and unusable (pls. 2-3).

The second test well (BIRH catalog No. 9933) was placed about $400 \mathrm{~m}$ from the Mediterranean shore and north of the depression created by pumping (pl. 1). The nearest well to this test well yields water with about $3,000 \mathrm{ppm}$ of dissolved solids, but other wells nearer to the sea yield highly saline water. The purpose of the test well was to determine the relations of saline to fresh water at depth. The deposits penetrated by this well were also prevailingly sandy silt and clay but, on the basis of the lithologic and electric logs, were somewhat less permeable than those penetrated at test well 1 . The zone 32 to $112 \mathrm{~m}$ probably contains water having dissolved solids of 2,000 to $4,000 \mathrm{ppm}$. The zone from 124 to $162 \mathrm{~m}$ probab'y contains water which is usable but may have dissolved solids of about 3,000 to $4,500 \mathrm{ppm}$ (pl. 2). The water in all permeable zones bolow about $162 \mathrm{~m}$ is mediocre or saline. A thin bed penetrated at about 40 to $42 \mathrm{~m}$ probably contains saline water, and this may be evidence of seawater encroachment in the area.

The third test well (BIRH catalog No. 9935), the only one of the four test wells drilled that was cased and tested for production, was drilled in the vicinity of a low ridge of brackish ground water east of Qaşr Hallāl (pls. 1-2). The most permeable zone, consisting mainly of silty sand, was found at depths between 37 and $64 \mathrm{~m}$. The water 


\section{EXPLANATION}

\section{$\triangle \underline{8301}$}

Destroyed test hole and catolog number

$$
\text { () }-\frac{48}{1340}-
$$

Dug well, with pump

$$
0 \frac{40}{1090}
$$

Dug well, without pump

Upper number indicates depth, in meters. Lower number indicates con. ductivity, in micromhos

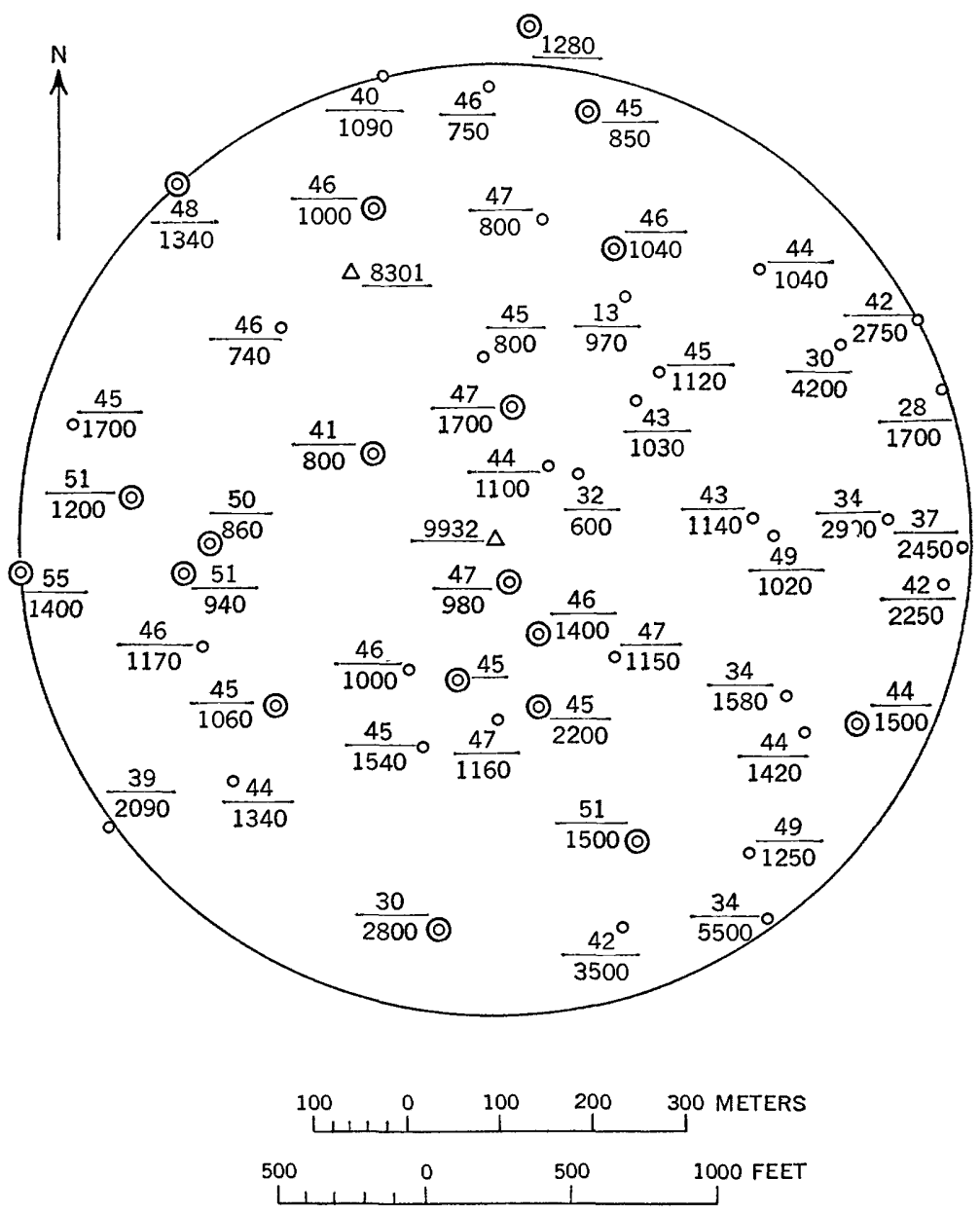

Figure 3.-Wells less than 500 meters from test well 1 at Tabulbah. 
quality was estimated to be poor but usable and to have a dissolvedsolids content of 3,000 to $4,500 \mathrm{ppm}$ (pl. 2). The hole was drilled to a depth of $62.5 \mathrm{~m}$, reamed to a diameter of $17 \% 3$ inches, and an 8-inch casing was installed inside a gravel pack which extended to land surface. The casing was slotted with louver-type perforations between 42.3 and $57.8 \mathrm{~m}$. Although it was impossible to obtain adequate tests of production and drawdown because of poor development and because of the long time between drilling and testing, the yield obtained was about 1 liter per second or 15 gallons per minute with excessive drawdown. It appears certain that yields from properly constructed and developed wells in the area would be significantly greater.

The fourth test well (BIRH catalog No. 9934, pl. 1) was drilled near the sabkha south of Țabulbah to determine the water quality in the deeper deposits there. The water quality was poor and unusable, and the hole was not cased, developed, or tested.

\section{OCCURRENCE OF GROUND WATER}

Ground water of usable quality (less than $4,000 \mathrm{ppm}$ dissolved solids) occurs in the shallow deposits of the Tabulbah area at depths ranging from near land surface to $160 \mathrm{~m}$.

The depth to the top of the water body is highly irregular, depending upon the altitude of the land above sea level, or the seibkha, and the location of the well in relation to the large water-table depression developed by a concentration of pumping near Tabulbah (fig. 3). Leveling was completed to only 95 of the wells (Dutcher and Mahjoub, 1962 , table 3) and, therefore, figure 3 shows only the depth to water below land surface. In general, there is a narrow zone extending along both the border of the sea and the sabkha where the depth to water is less than $10 \mathrm{~m}$. Between the two bordering zones of shallow water there is a broad area beneath which the water levels are generally 10 to $20 \mathrm{~m}$ below the surface but within which there are irregular areas where the depth to water is 20 to $30 \mathrm{~m}$. In an area near Tabulbah pumping has created a most striking depression, the water levels being 30 to $55 \mathrm{~m}$ or more below the land surface (pl. 1). Smaller depressions have developed around pumped wells near Al Muknin and near Aş Şayyādah and also around wells about $2 \mathrm{~km}$ east of Qaşr Hallal where there is heavy withdrawal by dalous for irrigation. Water levels are within $10 \mathrm{~m}$ of the land surface in an area extending eastward from Qașr Hallāl for about $2 \mathrm{~km}$.

Section $A-A^{\prime}$ (pl. 3) extends eastward from Qașr Hallall to the sea and crosses the area of shallow water table, the deepest part of the Tabulbah pumping depression, and an area northeast of Tabulbah where most wells have been abandoned because of the high salinity of the water $(5,000$ to $8,000 \mathrm{ppm})$. Within the Tabulbar pumping 
district along this section, the water level in several wells stands a few meters above the piezometric surface depicted by other wells in the vicinity.

Section $B-B^{\prime}$ (pl. 3) extends eastward along the seacoast from Aș Șayyādah to the sea and crosses several of the smaller pumping depressions, the north margin of the Tabulbah pumping depression, and the area northeast of Tabulbah where most wells have high water salinity. The altitudes of many of the wells along this section were determined by spirit level. The section shows clearly that the top of the zone of saturation is not definable, that water levels in wells reflect only local conditions, and that marked differences in water levels occur in closely spaced wells.

A water-level profile along section $C-C^{\prime}$ (pl. 3) extending northward from the sabkha to the sea near three of the test wells and the deepest part of the pumping depression west of Tabulbah shows that the water table as depicted by water levels in wells is extremely irregular.

The extent and continuity of individual sand beds or of the less permeable beds which act as confining layers between these beds or aquifers are not known. The method of development of all wells is such that ordinarily only one saturated aquifer is explored at a time, but in many of the deeper wells there is leakage from sand beds several meters above the bottom. In some areas marked differences in static levels in adjacent wells indicate separate and distinct aquifers and may also indicate a lenticularity of aquifers.

\section{SOURCE, MOVEMENT, AND DISCHARGE}

Natural replenishment of the shallow ground-water reservoir is by precipitation with downward movement through sandy or silty soils, croute calcaire, and underlying deposits. Because of the arid climate and the relative impermeability of many of the soils and underlying materials, the average rate of replenishment is low. In some places the water reaching the aquifer is fairly fresh; in others it is mineralized during transit downward from the surface, so that the shallowest water is more mineralized than that at greater depth.

Withdrawals from wells have long been in excess of the average rate of replenishment, and the rate of withdrawal is increasing. Much water has been removed from storage, and the upper limit of the saturated zone, which under natural conditions 2,000 years ago was presumably above sea level throughout the area, is now below sea level under part of the area, mainly where pumping is greatest, near Tabulbah.

Estimates of the annual recharge were not made during the study for the following reasons: (1) The present annual withdrawal by pumping and by dalous probably is greatly in excess of the annual $210-422-66-2$ 
recharge. (2) A reduction in withdrawal (or an increase) would not materially increase or change the natural recharge except $b y$ inducing inflow of saline water because the aquifer is not full; that is, presently little or no recharge is being rejected by the aquifers because of a lack of available storage space; the natural discharge by subsurface flow to the sea or sabkha is very small (presumably negligible) and probably cannot be greatly changed by variation in the pumping regimen. (3) Under the existing conditions the amount of annual recharge is only of academic interest; to make an estimate of the quantity would be very costly and would have little or no practical value; whether the recharge is or has been large or small is not important now in regard to the amount of water available for annual use.

Under existing conditions, therefore, annual recharge and perennial yield are not as important as the following considerations: (1) The amount of usable ground water in storage and the storage capacity of the ground-water reservoir, (2) the most likely future annual draft and the length of time that the available supply will last, and (3) problems relating to the chemical quality of water.

Present (1963) conditions are favorable for inflow of sea water and water from the sabkha to the reservoir, but such intrusion is not known to have progressed inland as much as half a kilometer at any point. Throughout the reservoir inferior water may also drain from finer textured deposits as water is withdrawn by wells from contiguous sand beds.

Because of the slow rate of inflow of inferior water from the sea, sabkha, and surrounding area, as well as downward drainage from overlying strata, the optimum use of water is logically achieved by continuing to deplete the storage in the reservoir at a rate which will allow users to obtain a blend with the inflowing water that will be usable for irrigation. This will certainly require continuing the withdrawal of water at a rate greater than the limited natural replenishment from precipitation. In other words, water balance cannot be maintained if the reservoir is to be utilized to best advantage.

Discharge from the shallow ground-water reservoir in the Tabulbah area is, as previously stated, principally by withdrawal from wells but it is in very small part by subsurface flow to the sea snd to the sabkha. The annual amount of such subsurface flow was not estimated during the present investigation for the following reasons: (1) At present (1963) the small amount of outflow from the area will be reduced annually as water levels decline owing to pumping, (2) outflow will probably stop eventually and inflow of saline water will exceed outflow (this may be the status at present), and ( $₹$ ) because the water in surrounding and underlying sediments and in the sea 
and sabkha is of inferior chemical quality, a reduction in annual pumping would probably result in a general chemical deterioration of the water in the aquifer which is now usable.

\section{WATER-LEVEL FLUCTUATIONS IN WELLS}

Beginning in February 1961 water-level measurements were made monthly in 35 selected wells in the Tabulbah area, and these data are given in table 6 of the separate data report (Dutcher and Mahjoub, 1962). Records of water levels in a few individual wells have been kept for a much longer period, and during 1940 water-lerel measurements were made in 94 wells. The static levels in the 94 wells visited in 1940 defined a highly irregular surface that could be c'spicted but not satisfactorily explained. There was an indication of a groundwater ridge extending eastward from Qașr Hallal, with a crest about $10 \mathrm{~m}$ above sea level at the town, and descending to sea level about $4 \mathrm{~km}$ to the east. Farther east, near Tabulbah, there was a depression about $2 \mathrm{~km}$ in diameter where the static levels in wells were more that $5 \mathrm{~m}$ below sea level, and in 10 wells the water levels were 10 to $18 \mathrm{~m}$ below sea level. Except along this central ridge and depression, the water levels in wells were generally within a few meters of sea level.

When the same 94 wells were revisited in 1960 , it was evident that withdrawals by pumps and dalous must be indeed creating irregularities in the water table (see pl. 3). In 1960 the ground-water ridge near Qaşr Hallāl was little changed but was cut off sharply to the east. The depression was little changed near Tabulbah but had extended westward and deepened in the western part.

It became obvious that the 94 wells which it was roped would provide sufficient data to portray the hydrologic conditions in the $40-\mathrm{km}^{2}$ area were inadequate for the purpose. It was desided, therefore, to collect data from most wells in the area. This decision was modified after the inventory reached 625 wells, and the magnitude of the task remaining was seen.

The fluctuations of water levels in the wells which were measured periodically (Dutcher and Mahjoub, 1962, table 6) are shown by the relatively short-term hydrographs on plate 4 . The wells are divided into seven groups based on similarity of fluctuations, depth to water below land surface, and location of the well in relation to the large pumping depression and individual wells pumped heavily.

Group 1 includes wells 4755, 4764, 9318, 9405, 10003, 1.0071 (pl. 4). Except for well 4764, all are beyond the margin of the large pumping depression and have depths to water of less than $30 \mathrm{~m}$. The records for these wells are not of sufficient length for use in predicting the long-term expectable rate of water-level decline in the area surround- 
ing the pumping hole, but for the period of good records (1960-62) the data indicate that relatively little change in water level has occurred. However, during the winter and spring of 1961-62 there was a rapid rise of water level at four of the wells; water rose to about $2.7 \mathrm{~m}$ at well 4764 . Because surface water is prevented from running directly into these wells, the rise of water level from winter to spring must have been caused by water from one of four sources, as follows: (1) Deep penetration of rainfall during that time when there was about average precipitation, (2) deep penetration of irrigation water applied to the land previously, (3) seepage of surface water impounded near the wells, or (4) leakage of water into the wells from sand beds or lenses higher than the water surface in each well. Eecause an equally rapid water-level decline followed the recovery, it appears unlikely that the aquifers were recharged by deep pentiration of rainfall or irrigation water over an extensive area. Thus, it is concluded that these fluctuations were caused either by limited recharge very near to the individual wells or by leakage of water into the wells from deposits overlying the main water table at the wells.

At well 10071, which has the shallowest water level (7 to $8.6 \mathrm{~m})$, there was no corresponding water-level rise during the period. Evidently no saturated sands overlie the shallow water table at this well.

In this group of wells the water-level recovery during the winter and spring of 1961-62 was greatest at well 4764, which is in the area of greatest pumping and deepest water levels (see also the hydrograph for nearby well 10042 , pl. 3, group 5). Well 4764 penetrates a water body presumed to be perched or semiperched above the general water table of the area (pls. 1 and 3). In well 10042, only about $100 \mathrm{~m}$ away, the water level was more than $28 \mathrm{~m}$ deeper in March 1962. Therefore the recharge to the aquifer during the spring was probably derived from overlying sand beds. If this is so, the fluctuations do not represent true recharge but only transfer of water from. one sand bed to another during a wet period when there was little water use or withdrawal.

"On the basis of a single measurement made in 1940 for well 4755 northwest of Tabulbah near the coast, the record suggerts that a rise in water level of nearly $5 \mathrm{~m}$ must have occurred during the relatively wetter than average periods $1949-52$ and 1956-59. However, at that well a decline in water level has been nearly continuous since May 1960.

The wells of group 2 (pl. 4) include 4779, 4805, 8500, 9554, 9655, and 9657. Of these, 4805 and 8500 are near Aș Șayyādah, 9655 and 9657 are within a local area of relatively large withdrawal east of Qașr Hallāl, and 4779 and 9654 are near the coast and northwest of the area of heaviest pumping and the pumping depression at Tabulbah. 
The water-level fluctuations in the wells of this group show clearly the effects of water withdrawal, except at well 4805 east of Aș Şayyādah. At well 9657 the range of water-level fluctuation has been more than $21 \mathrm{~m}$, from $24.84 \mathrm{~m}$ in February 1961 to $46.50 \mathrm{~m}$ in August of the same year. Although during the period 1؟31-62 the rate of water-level decline has been great at most of the wells of group 2 , it is probable that the smaller and more or less uniform lowering of level at well 4779 (pl. 4, group 2) is typical of the waterlevel decline in much of the Tabulbah area outside the pumping depression where water levels are more than $30 \mathrm{~m}$ below the land surface (pl. 1). Here the rate of decline during the last 2 years has been about $1 \mathrm{~m}$ per year, but if the period of record 1940-62 is considered, the rate of decline would only be about 0.1 to $0.15 \mathrm{n}$ per year.

Group 3 (pl. 4) includes wells 9364 and 9416 , and group 4 includes wells 4758,9274 , and 9401 , all west of Tabulbah. The rater level fluctuations in these wells are plotted on the hydrographs on plate 4 . Wells of group 3 clearly show a rise of water level during midsummer. This midsummer water level rise is undoubtedly due to the common practice of pumping water beginning in the fall for irrigation of vegetables to start crops before the fall rains; a gradual decrease in pumping occurs during the rainy season from October to April; pumping increases markedly again during the spring but decreases sharply at harvest time before the hot, dry summer. T'ius, there are 2 to 3 months during the hottest period when water levels in wells recover due to a lack of pumping.

The hydrographs of wells in group 4 more clearly show the effects of much more pumping and less clear-cut seasonal use of water than those of group 3.

The hydrographs for wells in groups 5, 6, and 7 (pl. 4) show combinations of nearly all the types of water-level fluctuations discussed previously. These wells are either within or near the large pumping hole northwest of Tabulbah where intermittent pumping: from the closely spaced wells in the area has caused a confused patter 1 of waterlevel fluctuations, or they are in the western part of the area where there locally is limited use of water. A comparison of the graph for well 10042 (group 5) with that of well 4764 (pl. 4, group 1) shows a marked difference in both the depth to water and in the pattern of the fluctuations in these two wells which are less than $100 \mathrm{~m}$ apart. Well 10042 is heavily pumped by dalous but well 4764 is unused.

\section{RATE OF WATER-IEVEL DECLINE}

Certainly the most critical ground-water problem in the Tabulbah area is the rapid rate of water-level decline in the area of largest water withdrawal. The graphs of water-level fluctuations based cn measure- 
ments made periodically in selected wells can be used to show definitely only these changes which have occurred in the past; unfortunately the records are for a relatively short period, mainly $19^{2} \cap-62$, and were made during a period of greatly expanded withdrawal of water by pumps and dalous. It appears probable that the use of water for irrigation in the area nearly doubled after 1959. Thus, the very high rate of water-decline shown by many of the hydrographs on plate 4 will probably not continue for more than a year or two, even if the annual withdrawal is not reduced. On the other hand, if more motor-driven pumps are installed and the overall withdrawsl increases, the rapid water-level decline suggested by the hydrographs will continue or even increase. The average annual water-level decline during the last few years has probably been about 2 to $3 \mathrm{~m}$.

The present (1963) average rate of water-level decline beneath most of the area (outside the deep pumping depression or near local wells pumped heavily) is probably about 0.2 to $0.3 \mathrm{~m}$ per year, based on the water-level measurements in wells. In the areas where the depth to water is 20 to $30 \mathrm{~m}$ and the chemical quality is good (less than $2,000 \mathrm{ppm}$ dissolved solids), the present rate of water-level decline probably averages about 0.8 to $0.9 \mathrm{~m}$ per year. In the most important area where the depth to water is greater than $30 \mathrm{~m}$ and the water contains less than $2,000 \mathrm{ppm}$ dissolved solids, the waterlevel measurements indicate that the annual rate of decline may average about $2 \mathrm{~m}$ per year and that this rate is exceeded at a few wells where withdrawal is more than average.

\section{QUALTTY OF GROUND WATER}

Chemical analyses of water samples from 120 wells in the Tabulbah area are included in table 4 of the data report (Dutcher and Mahjoub, 1962). Two or more analyses are available for many of the wells, including many of the 94 wells visited during the incompleted study of the area made in 1940 . In addition, measurements of the conductivity of water from 495 wells were made in the field during this investigation (Dutcher and Mahjoub, 1962, table 2). Thus, there is rather complete information on the chemical quality of the water in the depth range penetrated by existing wells. The water-quality data available for the deeper zones are limited because only the electric logs of the four test wells drilled in 1961 can be used to estimate the quality of water in zones deeper than $75 \mathrm{~m}$.

The general chemical quality of water in the zones penetrated by dug wells is shown on the map on plate 5. There is a remarkable similarity between this map and the map showing depth to water (pl. 1). These maps show that the area underlain by water of the best chemical quality (less than 1,000 ppm of dissolved solids) is 
also where most of the wells equipped with pumps are located and is the area of deepest water levels. Pumping obviously has been greatest where the best water is available, and the water-level decline has been greatest in the same area.

However, further examination of the water-quality rap (pl. 5) shows that the quality of water is highly variable from place to place and that the water-quality problems are neither simple nor all related to obvious features of the geology, depth to water, or other causes. A summary of the problems relating to the chemical qual ty of water follows.

In many parts of the Tabulbah area wells are not used because the salinity of their water is too great for use in irrigation. Based on local experience, the permissible limit for water used for irrigation of fruit trees is somewhat greater than $3,000 \mathrm{ppm}$ dissolved solids, a value usually considered excessive in the United States. Some of the wells encountered saline water when first dug, others originally yielded fresh water and might have been used for many years before the salinity became excessive. Knowledge of the sources of this sqlinity, and particularly the reasons for the changes, are of critical importance in managing the ground-water reservoir to provide the optimum quantity of usable water. The ground-water reservoir, which at least locally contains water with modest amounts of calcium, magnesium, sodium, and chloride, is bounded on several sides by more saline waters. The sea, the sabkha, the underlying saline aquifers, and tre surrounding and overlying deposits are all potential sources of cortamination.

Measurements of the conductivity of the water in wells during March 1961 (pl. 5) indicate that the water pumped from the depression west of Tabulbah is the least mineralized (600 to $2,000 \mathrm{ppm}$ dissolved solids). Water of good quality (less than $3,000 \mathrm{ppm}$ dissolved solids) is also found in wells in other areas of heavy withdrawal一at Al Muknīn, at Aș Șayyādah, and east of Qaşr Hallāl一and in wells along a narrow band parallel to the sea and corresponding in part to areas of outcrop of the croute calcaire and alon $\%$ a broader band extending from Tabulbah toward Al Baqaalițah under the plateau. In a broad area west of Tabulbah and continuing along the coast to Aș Şayyādah and in another area northeast of Al Muknin, the sampled waters had less than 2,000 ppm of dissolved solids. However, in an area extending northeastward from Tabulbah to the sea and in a smaller area within a kilometer of the sabkha, the dissolved solids in the waters exceeded 4,000 ppm.

The causes for the dissimilarities in chemical quality of water from place to place and the changes in water quality with time sre discussed in the following sections. 


\section{VERTICAL AND HORIZONTAL ZONATION OF WATER}

The shallow ground-water body beneath the area of largest withdrawal-the pumping depression northwest of Tabulbah-contains usable water down to a depth of about $160 \mathrm{~m}$ below land surface (pls. 2 and 5). Here the water-bearing deposits are divisible into three general zones: (1) A shallow zone extending to about $95 \mathrm{~m}$ below the surface where the saturated deposits contain water of gooc chemical quality (about 600 to $2,000 \mathrm{ppm}$ dissolved solids), (2) an intermediate zone of less permeability extending from about 95 to $160 \mathrm{~m}$ below the surface, the lower part (120 to $160 \mathrm{~m}$ ) of which is most permeable and contains water whose dissolved-solids content is estimated to be about 2,000 to $4,500 \mathrm{ppm}$, and (3) a deep zone extending from 160 to more than $275 \mathrm{~m}$ below the surface which has low permeability and contains water which is unusable for most purposes. There is the possibility of a fourth water-bearing zone at great depth in a sand aquifer of Vindobonian age but deep wells have not been drilled to test the existence of that zone beneath the area.

Northward from the area of greatest pumping, certain changes in the chemical quality of water are observed; at test well 2 (No. 9933) the same three zones are present, but the water contained in each is considerably more saline (pl. 2). Near the sea coast the shellow zone contains water having dissolved solids in excess of $2,000 \mathrm{ppm}$, the intermediate zone is probably also more saline, and the water of the deep zone is everywhere unusable. Southward from the area of greatest pumping, the water in the shallow zone is mediocre in quality and is estimated to contain 4,000 to $6,000 \mathrm{ppm}$ of dissolved solids (pl. 2). At test well 4 (No. 9934), however, the intermediate zone contains somewhat better quality water than the shallow zone and probably has about $4,500 \mathrm{ppm}$ dissolved solids.

It is very difficult to locate extensions of the three water-bearing zones westward from the area of the pumping depression and test well 1 (well 9933). Interpretation of the electric log and data from test well 3 (well 9935), however, indicate that the shallow zone is completely absent (pl. 2). The intermediate zone is apparently near the surface and extends to a depth of only about $65 \mathrm{~m}$, is poorly permeable, and contains water whose dissolved-solids content is about 3,000 to $4,000 \mathrm{ppm}$ or greater. Of course the quality of water in the deep zone is poor and the water is unusable for most purposes. In the western part of the area the shallow zone may be absent. Tre shallow zone penetrated in the pumping depression contains good vrater, but data from dug wells show that the water table is more than $10 \mathrm{~m}$ above sea level-higher than in any other part of the area-beneath an area extending eastward from Qașr Hallāl for about $2 \mathrm{~km}$ (pl. 1). The quality of water obtained from wells tapping this ground-water 
ridge is inferior to that in deeper wells to the south, nor ${ }^{2} h$, and east (pl. 5). This water and its dissolved mineral matter prc bably come from the intermediate zone which is at much greater depth farther east. However, there is a possibility that the water percolates downward from the surface, dissolving solids as it goes (geners lly 3,000 to $7,000 \mathrm{ppm})$.

Within the pumping depression several shallow wells have static levels several meters above those in adjacent deeper wells (pl. 3). These wells tap water which apparently rests on a relative'y impermeable bed probably left by the descent of the main water table. However, the water may be draining slowly from overlying deposits. The water in these shallow wells commonly has less dissolved solids than that in adjacent deeper wells and may be replenished in part by precipitation.

In the small areas northeast of Qaşr Hallāl where withdrawals have lowered the water table more than $35 \mathrm{~m}$ below the land surface, the water is of better quality than in the surrounding area where the water table is 10 to $30 \mathrm{~m}$ below the land surface. Moreover, in the vicinity of Tabulbah, the wells pumped by motor commonly have water of slightly better quality than that in adjacent wells where there is little or no withdrawal. These slight differences in the quality of water related to discharge may be an indication of variations in quality within the Quaternary deposits: better quality in the permeable sands which yield water rapidly to the wells; pcorer quality in the less permeable silts and clays which drain more slowly as underlying sands are unwatered. If after ground water in storage in a locality has been depleted by withdrawals from wells there is slow drainage of inferior water from the overlying finer textured deposits, a cessation or reduction in rate of withdrawal from some wells would result in increasing salinity of water in these wells.

Beneath a large area northeast of Tabulbah the dissolved-solids content in well water is 4,000 to $6,000 \mathrm{ppm}$ or more. The reason for this is obscure, but it appears possible that the permeable shallow zone found in the central part of the area is absent, just as appears to be the case in the western part of the area. Perhaps. in the beginning, the wells drilled northeast of Tabulbah penetrated a thin layer of good-quality water overlying more saline water at depth. Use of the wells may have started before their owners became aware that the supply of good-quality water was limited; the better quality water may have accunulated over a period of years by percolating downward from the surface after periods of greater than average rainfall. In any case, if the annual recharge is small and if only a thin layer of fresh water originally overlaid the more saline water, the fresh water would probably have been soon exhausted even by limited use. These 
circumstances would also explain how the water levels could remain virtually unchanged or in places actually rise when the dissolvedsolids content of the water increased considerably during the period 1940-62 (Dutcher and Mahjoub, 1962, table 4).

\section{SEA- OR SABKHA-WATER ENCROACHMENT}

In the area of greatest withdrawal, where water levels in wells have declined markedly, there were only slight changes in salinity of the water from 1940 to 1960 . In wells within a kilometer of both the Mediterranean and the sabkha there has been little or no decline in static level. Since 1940, however, the salinity has increased in these wells and in several wells remote from the sea, including some along the ground-water ridge near Qașr Hallāl.

The increasing salinity of water in wells near the sea and near the sabkha might be taken as evidence of salt-water encroachment toward the cone of depression, which by 1960 had a maximum depth of more than $30 \mathrm{~m}$ below sea level. But this simple explanation does not explain (1) why the wells remote from sea or sabkha, with static level several meters above sea level, had increased salinity during the 20year period, (2) the irregular pattern of salinity in wells near the sea, (3) the differences in static level and in salinity of water in adjacent wells having different depths, and (4) the basis for abandonment of wells. As previously explained, it is unlikely that extensive bodies of fresh water ever existed beneath the areas near the sabkha, along the coast, northeast of Tabulbah, or near Qaşr Hallal, where the dissolvedsolids content as shown on plate 5 exceeds $4,000 \mathrm{ppm}$. Instead, these areas may originally have contained only thin lenses or layers of fresh water overlying saline water. The shallowest wells produce the best water, but a large part of the good-quality water has been "skimmed" off by withdrawal in dalous; water in these areas has probably become "salty" as a consequence of using the very limited supply of fresh water originally available.

There is no evidence that sabkha-water intrusion has occurred. What about the threat of sea-water intrusion along the coast? About $120 \mathrm{~m}$ inland from the newly constructed breakwater northwest of Tabulbah, water in well 9584 has a salt concentration of about 80 percent of that of the sea. About $250 \mathrm{~m}$ from the shore, water in well 9582 has a salt concentration of about 40 percent of that of sea water. Here sea water has evidently not yet penetrated as far inland as $500 \mathrm{~m}$, where well 9589 contains water which has c aly about $3,000 \mathrm{ppm}$ of dissolved salts (7 percent of the salt concentration of sea water) and is comparable to ground water farther inland.

Along a section $500 \mathrm{~m}$ from the Mediterranean shore ard parallel to it (pl. 3), the static levels in wells are generally close to sea level, 
except where this section crosses the pumping depressior northwest of Tabulbah, and the static levels are 10 to $30 \mathrm{~m}$ belor sea level. The salt concentrations in wells along this section, as indicated by conductivity measurements, are generally similar to those of ground water farther inland. Adjacent to the pumping district. where the static levels are below sea level and where gradients are presumably favorable for sea-water intrusions, the water quality is superior to that in other parts of the section. Northeast of Tabulbqh this section passes through an area where the water from all wells has more than 5,000 ppm of dissolved solids. Even here, however, evidence of sea-water intrusion is lacking because the salinity does not decrease progressively with increasing distance from the sea.

In conclusion, it seems certain that sea-water intrusion occurred at only one place along the coast-near wells 9584 and 9582-and that as of March 1961 the inland movement of sea water had not anywhere exceeded $500 \mathrm{~m}$. However, the electric log for well 9933 indicates a zone of saline water that may represent a thin tongue of sea-water intrusion. In this vicinity water from the sec, may have reached as far inland as well 9933. Regardless of the small inland extent of the present intrusion of sea water, the potential is clear: water levels are below sea level; sea-water intrusion must be taking place, and it is only a matter of time before its effects are observable.

There is very little evidence that saline water is moving into the area of good-quality water from the immediately surrounding areas of inferior or poor-quality water on the east, west, and south. On the basis of the chemical quality of water at well 9274 near Tabulbah, however, such intrusion may be a serious threat. The dissolvedsolids content of the water from that well exceeded $3,000 \mathrm{ppm}$ in 1961; the well is equipped with a motor-driven pump and, according to the owner, formerly produced water of very good qual ty used for irrigation. According to the owner, the quality changed rapidly beginning in about 1958, and use was discontinued when the water became too saline for irrigation. A reduction of pumping in the shallow zone would probably not remove the throat of saltwater intrusion, which would probably continue even after pumping was reduced or stopped and cause a general deterioration in the chemical quality of the water still available for use.

\section{GROUND WATER IN STORAGE}

Before estimates of usable ground water in storage in an area can be made, it is first necessary to determine the factors limiting use such as chemical quality of the water, height of pumping lift, and yields from wells. In the Tabulbah area determination of these factors is very difficult; at one farm, water for irrigation of a par- 


\section{E24 HYDROLOGY OF AFRICA AND THE MEDITERRANEAN REGION}

ticular crop may be unusable because of its high miner l content, but often water of equal or greater dissolved-solids content is used for growing other types of crops at a nearby farm. For the purpose of this report water containing less than $4,000 \mathrm{ppm}$ dissolved solids is considered usable because such waters are presently (1963) being used in the area.

Because the yields from most of the hand-dug wells are small, the size of the yields does not appear to be a limiting factor in the use of water. Whether high-yielding wells could be drilled in deposits whose permeabilities are sufficiently high to permit water to be pumped economically is also not considered to be a limiting factor. All deposits outside the sabkha area are considered to contain usable water, provided that the deposits have sufficient average permeability to be recharged when they are unsaturated or to yield a limited flow of water to hand-dug wells when saturated.

Estimating the maximum distance that ground water can be lifted to the surface and still be considered usable introduces the following economic considerations: (1) The cost of obtaining water from alternate sources, (2) whether the water is for domestic, agricultural, or other uses, and (3) whether withdrawal of water for use will induce inflow of chemically inferior water from the sea or elsewhere.

In the following discussion of ground-water storage capacity of the area, two storage units are used, as follows: Storage unit 1 (fig. 3) extends downward beneath the entire surface area (excent beneath the sabkha) from an arbitrarily selected depth $10 \mathrm{~m}$ kolow land surface to the base of the intermediate water-bearing zone at a depth of $36 \mathrm{~m}$ below sea level at test well 3 (No. 9935). Thus, storage unit 1 underlies an area of about $4.45 \times 10^{7} \mathrm{~m}^{2}$ and has in average thickness of about $55 \mathrm{~m}$.

The boundaries of storage unit 2 , as shown on plate 1 , were chosen because data necessary for more precise selection are lacking. This unit extends downward beneath storage unit 1 , but only in the central part of the area which is underlain by the shallow water-bearing zone that contains good-quality water. The base of storage unit 2 was selected to correspond to the base of the intermediate water-bearing zone at test well 1 (well 9932) at a depth of $160 \mathrm{~m}$ below the surface (140 $\mathrm{m}$ below sea level). The boundaries of unit 2 were placed to include nearly all the most permeable deposits and water of good quality above a depth of $140 \mathrm{~m}$ below sea level and below storage unit 1. At places along the borders of the unit, the waten at depth within the unit may contain more than 4,000 ppm of dissolved solids; at other places along the borders the water of good quality in the shallow deposits may extend outward beyond the indicated border. The borders were placed on the basis of the meager data available and 
so that vertical differences in water quality would average out to the greatest extent possible. Also, an effort was made to keep the area of storage unit 2 to a size which would include only water of good quality in order that the estimation of usable ground water in storage would be less rather than more than the actual quantity that can be recovered by pumping.

Thus, the ground-water body in storage unit 2 (pl. 1) that underlies storage unit 1 has an area of $7.24 \times 10^{6} \mathrm{~m}^{2}$ and a thickness of $95 \mathrm{~m}$.

Estimating the amount of usable ground water in storgge in the Tabulbah area is much more complicated. Areas underlain by saline water having dissolved solids greater than about $4,000 \mathrm{ppm}$ must be eliminated. This is difficult because only meager data are available to estimate the vertical and horizontal extents of the deeper waterbearing zones. In an attempt to estimate conservatively the usable ground-water in storage, only one storage unit was selected and it conforms exactly in outline to storage unit 2 (pl. 1). Horrever, the vertical extent of the unit containing usable ground water in storage differs from that of storage unit 2 because usable ground water in storage extends upward from the base of storage unit 2 to the water table. Thus, the exterior boundaries of the area used tc estimate usable ground water in storage were chosen so as to be ider tical with those used to estimate the storage capacity of unit 2 (pl. 1), but the top of the usable ground water in storage is nearly everywhere in storage unit 1 . Usable ground water in storage extends downward from the water table of March 1961 to the base of storage unit 2.

\section{GROUND-WATER STORAGE CAPACITY OF THE DEPOSITS}

Storage units 1 and 2 (pl. 1) contain ground water which is in part unusable because of the high dissolved-solids content. However, the amount and chemical quality of the water in these storage units are not considered in estimating the total ground-water storage capacity of the area; only the volume of the deposits and their estimated average field specific yield is used. This was done because it might be possible, by proper management and by recharging with good-quality water, to replace the poor-quality water with usable water imported into the area.

The field specific yield of a deposit can be defined as the ratio of the volume of water which, on the average and after a long period, would drain by gravity from a given volume of the orginally saturated material, expressed as a percentage. It was not possible to determine the average specific yield of the deposits in the Tabulbah area during the investigation; however, based on field and laboratory studies of the specific yields of similar materials and deposits made elsewhere, 
the average field specific yield of the deposits in ground-water storage units 1 and 2 was estimated to be at least 7 percent. In computing the usable ground water in storage a specific yield of 7 percent was also used.

The ground-water storage capacity of storage units 1 and 2 can each be estimated by using the formula

$$
S=A T S y,
$$

in which $S$ is the ground-water storage capacity in cubic meters, $A$ is the area in square meters, $T$ is the thickness of the deposits in meters, and $S y$ is the estimated average field specific yield of the deposits in percent. The estimated ground-water storage capacity of storage unit 1 (pl. 1) is

$$
4.45 \times 10^{7} \times 55 \times 0.07=1.7 \times 10^{8} \mathrm{~m}^{3},
$$

and that of storage unit $2(\mathrm{pl} .1)$ is

$$
7.24 \times 10^{6} \times 95 \times 0.07=4.8 \times 10^{7} \mathrm{~m}^{3} .
$$

Thus, the total ground-water storage capacity of the Takulbah area is estimated to be about $2.2 \times 10^{8} \mathrm{~m}^{3}(180,000$ acre-ft).

\section{USABLE GROUND WATER IN STORAGE}

Ground water of usable quality occurs mainly in the central part of the Tabulbah area in both storage units 1 and 2. Therefore, in computing the amount of usable ground water in storage in the area, only the water contained between the March 1961 water table and the base of storage unit 2 is included in the estimates. The averag" saturated thickness of the deposits between the average altitude of the water table and the base of the storage unit at $140 \mathrm{~m}$ below sea level was about $120 \mathrm{~m}$ in March 1961 . The average field specific yield of the deposits in the usable ground-water storage unit was estimated to be about 7 percent.

Thus, the usable ground water in storage in the Tabull $a \mathrm{~h}$ area in March 1961 (pl. 1) can be estimated by using the formula

$$
S u=A T S y,
$$

in which $S u$ is the usable ground water in storage and the other units are the same as those used in computing total ground-water storage capacity, and

$$
7.24 \times 10^{6} \times 120 \times 0.07=6.1 \times 10^{7} \mathrm{~m}^{3}(50,000 \text { acre-ft }) .
$$

Presumably, all this usable ground water in storage will contain less than 4,000 ppm of dissolved solids, but obviously not nearly that much usable ground water will have a dissolved-solids content of $2,000 \mathrm{ppm}$ 
or less. The meager data suggest that the zone between sbout $20 \mathrm{~m}$ below sea level (the approximate average altitude of the water table in March 1961) and $75 \mathrm{~m}$ below sea level contains the best waterabout $2,000 \mathrm{ppm}$ of dissolved solids or less. Thus, the amount of best quality ground water in storage may be estımated as follows:

$$
7.24 \times 10^{6} \times 55 \times 0.07=2.8 \times 10^{7} \mathrm{~m}^{3}(23,000 \text { acre-ft }) .
$$

Only by blending more than 30 million cubic meters of water of inferior quality with the water of better chemical quality can the full estimated 61 million cubic meters of water in storage be considered usable. If blending by pumping from both the deeper and shallower sands is not carried out, there is estimated to be less thar 30 million cubic meters of usable water remaining in the Tabulbah area. By blending water from the deep and shallow zone it appears that the usable supply could be more than doubled at some sacrifice in chemical quality of the blended waters.

\section{ADEQUACY OF THE WATER SUPPLY}

The total supply of ground water in the Tabulbah area is inadequate to meet the long-term needs for established irrigation and domestic use in the area. Water is being mined-the present (1963) annual rate of withdrawal exceeds replenishment-and intrusion of saline water from the sea is occurring locally and will continue under existing conditions. Water of inferior to unusable chemical quality is presumably flowing from sand beds or lenses surrounding the area of good-quality water and will continue to flow unless the hydrologic conditions are changed; relief from these circumstances cannot be expected to result from natural causes because the climate of this area is arid and presumably will remain so into the indefinite future.

Although ground water has been mined and the rate of use presently exceeds recharge, the reservoir has not necessarily been mismanaged. A considerable agricultural economy has been built by the permanent withdrawal of ground water, and a group of highly skilled farmers has been self-trained. Further, good reservoir management would not now dictate controlled reduction in withdrawal. On the contrary, under existing conditions a forced reduction in pumping would probably result in an overall deterioration in the chemical quality of much of the water which currently is the best available for irrigation. Thus, under existing conditions it would appear best to continue the present rate of withdrawal. Ground water is the chespest water available; it is pumped by hand or by modest, inexpensive equipment. The supply of good water, based on the estimated rate of water-level decline in wells, will probably not be in critical short supply for at least another 10 to 12 years at the present (1963) rate of withdrawal. 
It would last longer, perhaps 20 to 25 years, if the best vater were blended with waters of inferior chemical quality.

On the other hand, it appears obvious to the writers that some form of ground-water reservoir management will be necessary at some time in the future and that plans for such a program should be made. In the Tabulbah area any future ground-water reservoir management program will undoubtedly require that water be imported.

\section{RESERVOIR MANAGEMENT AND USE}

Within a few years a pipeline which will be part of the waterdistribution system for the Wādi Nabhānah dam and irrigation project (presently under construction) will carry water to the Tabulbah area. This pipeline will provide an excellent opportunity for conjunctive use of surface (or imported) water with cyclic ground-water storage. A combined reservoir-management and irrigation program would have the following advantages: (1) Presumably, the freshwater aquifer could be recharged by flow into part of the many hundreds of hand-dug wells; this recharge would cause the water levels in wells to rise and increase the usable ground water in storege during the winter or at times when the water is not needed elsewhere. Thus, recharge would help to prevent encroachment of sea water or other saline water and, if extensively carried out, would replace water of poor or unusable chemical quality and increase the size of the usable ground-water reservoir. (2) Such a plan would in effect increase the overall size of the surface reservoir behind the Wādi Nabhānah dam because during times of surplus, water could be transported to the Tabulbah area for storage in the ground. (3) Water placed in deep underground storage where it is later recoverable by pumping is not subject to losses by evaporation or transpiration and thus is the best means of conservation. (4) The pipeline from the dam could be effectively used during all seasons-during the rainy seasor to transport water for domestic use and ground-water recharge and during dry periods or the irrigation season to transport only water for direct use; also the pipeline load during peak-demand periods could be reduced by recharging the aquifer during the hours or seasons when other water demand is the least. (5) Infrequently, during future wet periods when rainfall exceeds the average for several consecutive years ths reservoir behind the Wādi Nabhānah dam will be filled to overflowing and a considerable quantity of water could be recharged in to the Tabulbah aquifer that otherwise would be lost to use. Continued use of the many existing hand-dug wells for irrigation would probably save a considerable investment in a surface-water distribution, system for irrigation. 


\section{REFERENCES}

Cointepas, J. P., 1959, Les sols de la zone côtière entre Sidi Bou Ali eł Mahdia: Groupe de l'Hydraulique et d'Aménagements Ruraux, Sec. Spéciale d'Etudes de Pédologie et d'Hydrologie, 23 p., 7 annexes.

Department of the Interior, Office of Geography, 1964, Tunisia: Washington, U.S. Govt. Printing Office, Gazetter no. 81.

Dutcher, L. C., Mahjoub, M. S., 1962, Tables de rensignements se rapportant aux puits creuses à la main et aux sondages et forages de la région de Téboulba, Tunisie: Groupe de l'Hydraulique et de l'Equipement Rural, open-file rept. (in French), $62 \mathrm{p}$.

Thomas, H. E. and Dutcher, L. C., 1961, Ground-water dilemma at Téboulba, Tunisia ; in Internat. Assoc. Sci. Hydrology, Symposium of Athens, Ground Water in Arid Zones: v. 2, pub. 57, p. 597-604. 